UDC 377.8:011.3-051:796

DOI: $10.31470 / 2415-3729-2019-9-195-210$

\title{
Psychological and Pedagogical Conditions for the Future Physical Education Teachers Training in the Educational Process of the New Ukrainian School
}

\section{Iryna Fastovets}

Specialist of the Highest Qualification Category, Teachermethodologist,

Lecturer of the Kyiv Higher Educational Institution of Kyiv

Region Council

«Bila Tserkva Humanities Pedagogical College»

$\bowtie$ 37, Yaroslava Mudrogo Str., Bila Tserkva, Ukraine

E-mail: fastovets.ira12@gmail.com

ORCID: 0000-0002-7437-8263

\section{Nadiia Ovcharova}

Specialist of the Highest Qualification Category, Teachermethodologist,

Lecturer of the Kyiv Higher Educational Institution of Kyiv Region Council

«Bila Tserkva Humanities Pedagogical College»

$\triangle$ 37, Yaroslava Mudrogo Str., Bila Tserkva, Ukraine

E-mail: ovcharovik@ukr.net

ORCID: orcid.org/0000-0003-1447-7478

Date of receipt of the article: December 04, 2018 Article accepted for publication: February 21, 2019

\section{Психолого-педагогічні умови підготовки майбутніх учителів фізичного виховання Нової української школи}

\section{Ірина Анатоліївна Фастовець}

спеціаліст вищої кваліфікаційної категорії, педагог-методист, викладач Київського вищого навчального закладу 
Київської обласної ради «Білоцерківський гуманітарний педагогічний коледж»

$\square$ вул. Ярослава Мудрого, 37, Біла Церква, Україна

\title{
Надія Андріївна Овчарова
}

спеціаліст вищої кваліфікаційної категорії, педагог-методист, викладач Київського вищого навчального закладу

Київської обласної ради «Білоцерківський гуманітарний педагогічний коледж»

$\bowtie$ вул. Ярослава Мудрого, 37, Біла Церква, Україна

Дата надходження статті: 04 грудня 2018 р.

Стаття прийнята до друку: 21 лютого 2019 р.

\begin{abstract}
The article presents the theoretical substantiation of the implementation of pedagogical innovations aimed at increasing the efficiency of the New Ukrainian School. It sets the task of scrupulous analysis, awareness and comprehension of the circumstances on which the effectiveness, success, quality of education depend on. The pedagogical conditions under which their implementation is possible in the preparation of future Physical Education teachers are determined by the authors. They note that the results of the long-term scientific and pedagogical research during the pre-diploma practice of graduate students convincingly testify that the professional development of future teachers and scientific and pedagogical workers are linked inseparably. There are situations that stimulate the teachers of psychological and pedagogical disciplines for a self-development during the introduction of psychological and pedagogical conditions: the self-improvement of their own competence, the methodically competent selection of professional-practical tasks, and the work on research projects. The pedagogical conditions and other aspects of this article concern both the main subjects of education, although they are aimed, viewing the goal and objectives, mainly for the training of future Physical Education teachers. The effective professional development of students
\end{abstract}


requires taking into account the social, individual and characterological characteristics of each individual. The learning system should develop the students' ability to comprehend, study, analyze, make informed decisions, take into account different options for solving practical problems. The stimulation of the professional teachers' activity involves the creation of such circumstances and the psychological atmosphere, when their active creative activity achieves high results, satisfies their personal and social needs, which leads to the formation of positive motives in their professional and pedagogical activity. The article presents the theoretical substantiation and methodology of physical education features in the educational process in pre-school educational institutions, the formation of physical health and cultural skills that have a positive effect on physical development, emotional state of children, diverse classes.

Key words: professional competence, professional motivation, professional and pedagogical training of students, physical education, healthcare, New Ukrainian School.

\section{References}

1. Azhippo, O. Y. (2012). Pidhotovka maibutnikh uchyteliv fizychnoi kultury do profesiinoi diialnosti $\mathrm{V}$ zahalnoosvitnikh navchalnykh zakladakh [Training of physical culture future teachers for a professional activity in general educational institutions]. Kharkiv: Digital Printing House, 1, 423 [in Ukrainian].

2. Balakhnicheva, G.V., Zaremba, L.V. \& Tsos, A.V. (2013). Profesiina maisternist uchytelia fizychnoho vykhovannia [Professional mastery of a physical education teacher]. Lutsk: Lesia Ukrainka Eastern Europe National University [in Ukrainian].

3. Vasyanovich, G.P. (2013). Pedahoh i yoho rol u navchalnovykhovnomu protsesi [The teacher and its role in an educational process]. Officer of Ukraine, 8, 9-11 [in Ukrainian].

4. Vasyanovich, G.P., 2005. Pedahohichna etyka [Pedagogical ethics]. Lviv: Norma [in Ukrainian]. 
5. Gurevich, R. S. \& Cademia, M. Y. (2005). Informatsiinotelekomunikatsiini tekhnolohii $\mathrm{v}$ navchalnomu protsesi ta naukovykh doslidzhenniakh [Information and telecommunication technologies in the educational process and scientific researches]. Vinnitsa: Ltd. «Planer» [in Ukrainian].

6. Gurevich, R. S. (2008). Teoriia i praktyka navchannia v profesiino-tekhnichnykh zakladakh [Theory and practice of teaching in vocational schools]. Vinnytsya: «Vinnytsia» [in Ukrainian].

7. Gurzhiy, A. M., Gurevich, R. S. \& Konoshevsky, L. L. (2015). Formuvannia profesiinoi kompetentnosti maibutnikh uchyteliv trudovoho navchannia zasobamy informatsiino-komunikatsiinykh tekhnolohii [Formation of professional competence of future labor education teachers by means of information and communication technologies]. Kyiv; Vinnitsa: Ltd. «Planer» [in Ukrainian].

8. Yevtuh, M. B. (2008). Pedahohichna osvita [Pedagogical education]. In V.H. Kremen (Ed.), Entsyklopediia osvity [Encyclopedia of Education]. Kyiv: Yurinkom Inter [in Ukrainian].

9. Zyazyun, I.A. (2000). Intelektualno-tvorchyi rozvytok osobystosti v umovakh neperervnoi osvity [Intellectual and creative development of a person in the conditions of continuous education] In I.A. Ziaziuna (Ed.) Neperervna profesiina osvita: problemy, poshuky, perspektyvy [Continuing vocational education: problems, quest, perspectives]. Kyiv: Vipol. 11-57 [in Ukrainian].

10. Zyazyun, I., Levovitsky, T., Vilsh, I., \& Nichkalo, N. (2001). Nauka i mystetstvo pedahohichnoi dii [Science and art of pedagogical influence]. Profesiina osvita: pedahohika i psykholohiia. Kyiv, 5, 357-380 [in Ukrainian].

11. Zyazyun, I. A. (2011). Pedahohichne naukove doslidzhennia v konteksti tsilisnoho pidkhodu [Pedagogical research in the context of a holistic approach]. Porivnialna profesiina pedahohika, 1, 19 [in Ukrainian].

12. Nychkalo, N. G. (2012). Teoretychni zasady stanovlennia i rozvytku subdystsyplin u suchasnii pedahohitsi 
[Theoretical foundations of formation and development of subdisciplines in modern pedagogy.]. Zhytomyr: Publishing House of Ivan Franko Zhytomyr State University. 23-33 [in Ukrainian].

\section{Вступ}

Для ефективної модернізації педагогічної освіти в українських 3ВО, зокрема підготовки вчителів фізичного виховання, відповідно до завдань, пов'язаних iз формуванням Нової української школи, необхідно достатньо повно та цілісно уявляти структуру й організаційні особливості вищої освіти розвинених європейських та інших розвинених країн, у тому числі основні напрями вдосконалення підготовки педагогічних кадрів.

Аналіз останніх досліджень і публікацій свідчить про те, що за кордоном галузь фізичної культури і спорту розглядають крізь призму практичної діяльності як складну систему соціально-економічних відносин. Останнім часом Уряди країн ЄC здійснюють заходи щодо пропаганди фізичної культури, затверджують національні програми популяризації фізичного виховання; більшість європейських країн на всіх ступенях загальної освіти (молодша, середня i старша школи) вимагають від учнів обов'язкового відвідування уроків фізичного виховання.Підготовка вчителя Нової української школи в наш час перебувають в центрі уваги педагогічної науки. Формування особистості майбутнього вчителя у процесі навчання представлене в роботах (Васяновича, 2013: 9-11; 2005: 344; Гуревича, 2005: 366; 2008: 410; Гуржія, 2015: 464; Свтуха, 2008: 646; Зязюна, 2001: 380) та ін. Отже, аналіз функціональних компонентів психолого-педагогічної компетентності вчителя фізичного виховання дає підстави стверджувати, що вони будуються на грунті загальнонаукових, загальнопрофесійних і професійно орієнтованих (теоретичних і практичних) дисциплін шляхом взаємозв'язку та інтеграції психолого-педагогічної та фізкультурно-спортивної підготовок. 
Тому головною метою є: проектування професійних якостей випускників 3ВО галузі фізичної культури на основі компонентів психолого-педагогічної компетентності, вивчення сучасних педагогічних концепцій та ідей компетентнісного підходу в освіті, а також досвіду моделювання особистості вчителя фізичного виховання. Моделювання дозволяє співставити інваріантні, ідеалізовані, узагальнені характеристики особистості фахівця, його професійної діяльності та, на цій основі, - удосконалити процес його формування.

Отже, незважаючи на значення проведених наукових пошуків, виділення невирішених раніше частин проблеми професійної підготовки майбутніх вчителів фізичного виховання у ЗВО недостатньо досліджена в теоретикометодологічному аспекті, а традиційна система освіти не в змозі забезпечити органічне входження нової генерації вчителів у складне та швидкозмінне поле різнопланових потреб навчально-виховної діяльності в Нової української школі.

Головною метою статті $\epsilon$ : формування цілісної особистості, що передбачає активний вплив не лише на їi фізичний потенціал, а й на свідомість, психіку та інтелект, сприяє формуванню стійкої позитивної мотивації, ціннісних орієнтацій, інтересів і потреб у фізичній активності та здоровому способі життя. Розвиток фахівців фізичної культури і спорту визначається компетенціями, необхідними для творчого розв'язання психолого-педагогічних завдань фізичного виховання молоді. Відповідно, важливе місце в підготовці фахівців цього профілю займають психологічні та педагогічні дисципліни, від яких залежить вироблення в них здатності ефективно застосовувати форми і методи роботи 3 учнями, креативно мислити, самостійно продукувати нові знання.

Тому постановка завдань полягає у визначенні психолого-педагогічних умов підготовки майбутніх учителів фізичного виховання та ефективному застосуванні їх у навчальному процесі. 


\section{Матеріал і методи досліджень}

Методи дослідження, які використовувалися для досягнення поставлених завдань: аналіз, синтез та узагальнення отриманих матеріалів.

\section{Результати та їх обговорення}

У зв'язку з цим педагогічні умови вдосконалення професійної підготовки майбутніх учителів фізичного виховання стосуються як структурних, так і функціональних компонентів розробленої освітньої системи. Специфіка фізичного виховання визначає конкретну спрямованість педагогічних умов, відповідно до змісту i структури освітнього процесу, які розрізняють: дидактичні, психологопедагогічні, організаційно-педагогічні, соціально-педагогічні та методичні умови.

Отже, основними передумовами якісної професійної підготовки майбутніх учителів фізичного виховання вважаємо належне соціально-психологічне, науковометодичне, кадрове і матеріально-технічне, у тому числі інформаційно-комунікаційне забезпечення освітнього процесу коледжу в галузі фізичної культури і спорту.

Розробляючи умови вдосконалення професійної підготовки, розглядаємо їх як психолого-педагогічні, оскільки у життєдіяльності колективів (педагогічного, навчального) особливе місце займає моральнопсихологічний стан його членів, соціально-психологічні обставини функціонування, діяльності та розвитку колективу. I це природно, оскільки колектив не може ні існувати, ні працювати без спілкування його членів, без взаємовідносин між ними, без їхнього соціально-психологічного контакту та взаєморозуміння. Під психологічними умовами розуміємо всю сукупність соціально-психологічних характеристик стану та діяльності колективу в цілому та його окремих складових, що в сукупності визначають соціальнопсихологічний клімат Нової української школи. У педагогіці соціально-психологічний клімат - це «емоційна атмосфера», що склалась у колективі та відображає систему міжособистісних відносин у ньому, що суттєво впливають на продуктивність освітньої діяльності майбутніх вчителів. 
Виходячи 3 цього, загальними (першого рівня конкретизації) умовами формування компетентності майбутніх фахівців з фізичної культури і спорту в системі професійної освіти, на нашу думку, присутні три групи умов:

- пов'язані з реалізацією сукупності принципів, вибір яких визначений освітньою сферою педагогічної діяльності;

- організації освітнього процесу, що забезпечує єдність знань і діяльності студентів, формування в них адекватних уявлень про майбутню соціальнопрофесійну дійсність і рольові функції, котрі вони виконуватимуть;

- реалізації принципових положень компетентнісного підходу в освіті, вибір яких визначається сутністю та цільовою спрямованістю цього підходу.

Отже, педагогічні умови можуть бути описані стосовно ефективності функціонування освітнього процесу (умови другого рівня конкретизації) як вимоги до цілеспрямованої професійної мотивації, становлення, ідентифікації та адаптації студентів; вибору змісту освіти; засобів, форм, прийомів і методів організації освітнього процесу; поведінки, діяльності та характеру взаємодії особистісних умови. За цією логікою поділяють психолого-педагогічні умови професійної підготовки вчителів фізичного виховання на такі підгрупи: мотиваційно-цільові, процесуально-змістові, організаційно-технологічні, суб'єктно-особистісні.

Натомість, сукупність умов, спрямованих на формування професійно-педагогічної майстерності в системі професійної освіти фахівців фізичної культури і спорту, включає: гуманізацію процесу навчання i виховання; вивчення мотивів і потреб студентів; коригування мотивів на підвищення педагогічної майстерності; розвиток суб' єктної позиції студента з урахуванням його активності, інтересів і потреб; наступність змісту курсів обраного виду спорту, спеціалізації та фізкультурно-педагогічного вдосконалення; етапність у формуванні педагогічної майстерності; інтегрування спортивно-спеціалізованого та психологопедагогічного вдосконалення; використання активних 
методів навчання та створення інноваційного середовища. Психолого-педагогічними умовами ефективної загальнопедагогічної підготовки майбутнього учителя фізичного виховання виступають: фундаменталізація навчального матеріалу; системна організація процесу пізнання педагогічної дійсності; формування методологічного мислення майбутнього вчителя; актуалізація людинотворчої сутності професійної діяльності учителя фізичного виховання; інтеграція теоретичної та практичної складової загальнопедагогічної підготовки.

Викладені умови охоплюють різні сторони навчання, відображаючи специфіку підготовки вчителів фізичного виховання, сприяють формуванню інноваційних знань, умінь, навичок, відповідних особистісних і професійних якостей студента, котрі забезпечують готовність майбутнього вчителя до інноваційної навчальної діяльності в Новій українській школі.

Результати тривалого науково-педагогічного пошуку під час передипломної практики студентів-випускників, переконливо свідчать про нерозривну єдність професійного розвитку майбутніх педагогів i науково-педагогічних працівників. Під час упровадження психолого-педагогічних умов виникають ситуації, що стимулюють викладачів психологічних і педагогічних дисциплін до саморозвитку: самовдосконалення власних компетенцій, методично грамотного добору професійно-практичних завдань, виконання науково-дослідних проектів. Як викладачів, так i студентів заохочують підвищувати педагогічну майстерність: незадоволеність власним рівнем професіоналізму, готовності до педагогічної діяльності, своїми досягненнями, статусом, визнанням серед інших фахівців галузі фізичної культури i спорту; прагнення пошуку нових життєвих стратегій, створення програми власного саморозвитку i вибору відповідних засобів, набуття досвіду самовдосконалення в реальних діях і вчинках, моделювання цілісної системи роботи над собою, розвитку власних інтелектуальних i фізичних здібностей. Педагогічні умови та інші аспекти статті стосуються обох основних суб'єктів освіти, хоч i 
спрямовані, 3 огляду на поставлену мету i завдання, переважно, на підготовку майбутніх учителів фізичного виховання. Зауважимо також, що цілеспрямована мотивація студентів і викладачів до навчання та педагогічної діяльності в галузі фізичної культури і спорту включає: урахування загального культурно-освітнього рівня студентів; активізація навчально-пізнавальної діяльності, залучення студентів до різних складових освітнього процесу; урахування впливу особистості викладача на професійно-педагогічний розвиток студентів.

Розвиток професійної мотивації майбутнього вчителя та перевірка його здатності забезпечувати в подальшому мотивацію освітньої діяльності учнів, має здійснюватися вже у процесі допрофесійної підготовки та профвідбору. До найважливіших характеристик освітнього процесу 3ВО, що визначають мотивацію професійно-педагогічної діяльності й ефективність професійної підготовки в цілому, як уже зазначалось, належить соціально-психологічний клімат у навчальному та педагогічному колективі. Організовуючи роботу з підвищення мотивації студентів і викладачів до навчання та педагогічної діяльності, варто враховувати показники, що характеризують стан соціальнопсихологічного клімату: задоволеність членів колективу взаємовідносинами, процесом діяльності, керівництвом; настрій, що домінує; взаєморозуміння студентів із викладачами, викладачів із керівництвом, авторитетність педагогів і керівників коледжу; ступінь участі членів колективу в управлінні та самоуправлінні; згуртованість, свідома дисципліна; продуктивність освітньої діяльності. На нашу думку, ці показники доцільно доповнити задоволеністю рівнем оплати праці та одержаними результатами професійної підготовки випускників.

Тому можна з упевненістю стверджувати, що діяльність 3 мотивації студентів і викладачів до навчання та педагогічної діяльності у галузі фізичної культури і спорту здійснюється за двома взаємопов'язаними напрямами: робота керівництва з оздоровлення клімату в педагогічному колективі та серед студентів і підвищення активності викладачів у створенні 
сприятливої

соціально-психологічної

атмосфери B навчальному колективі. При цьому ефективний професійний розвиток студентів потребує врахування соціальних, індивідуально-характерологічних особливостей кожної особистості. Динаміка професійного зростання та поступового формування професійно-педагогічної компетентності майбутнього вчителя фізичного виховання залежить від суб'єктної взаємодії «студент - викладач» i прямо пропорційна рівню професійної мотивації в освітньому процесі. Система навчання має розвивати у студентів здатність осмислювати, вивчати, аналізувати, приймати обдумані рішення, враховуючи різні варіанти виходу з педагогічних ситуацій, розв'язання практичних завдань. Стимулювання професійної діяльності викладачів передбачає створення таких обставин і психологічної атмосфери, коли їхня активна творча діяльність дає високі результати, задовольняє їхні особистісні та соціально зумовлені потреби, що зумовлює формування в них позитивних мотивів професійно-педагогічної діяльності. Для формування індивідуальних соціально та професійно важливих якостей, розвитку навичок спілкування, формування мотивації до професійно-педагогічної діяльності та професійної спрямованості викладачів і студентів доцільно використовувати тренінгові технології.

Особливістю навчання педагогічних працівників Нової української школи є необхідність врахування факторів, що допомагають долати сформовані в їхній свідомості негативні стереотипи щодо опанування нових знань, професійних навичок i вмінь. У цьому зв'язку однією з провідних тенденцій, що набуває нині суттєвого значення, є посилення уваги до психологічної складової навчання та відповідного психологічного супроводу професійної підготовки, формування у випускників готовності до вікових i професійних змін, що відбуваються 3 людиною впродовж життя, і максимальна профілактика можливих професійних деформацій, зокрема професійного вигорання вчителя. Це особливо важливо для учителів фізичного виховання, завдання яких - не лише фізична підготовка, а й моральнопсихологічний розвиток учнів. 
На сьогодні в Новій українській школі повинно бути обов'язковою складовою ефективна діяльність вчителя фізичної культури та належний рівень психологопедагогічної компетентності. Якщо студент не оволодів психолого-педагогічними знаннями, вміннями, професійними якостями, він не зможе в подальшому правильно підійти до аналізу професійних функцій, що створить значні труднощі для його педагогічної діяльності. Робота в Новій українській школі має розглядатися не «як система навчальних предметів, а як, відповідно, предмет навчальної діяльності, що ставить студента в дієву позицію, забезпечує змістову реалізацію принципу зв'язку теорії 3 практикою».

У модернізації змісту освіти майбутніх учителів фізичного виховання у коледжі вирішальну роль відіграють критерії добору змісту навчальних дисциплін, що мають забезпечувати точність, достовірність, відтворюваність, доказовість, логічну стрункість навчальної інформації. Навчальні програми варто наповнювати науковими знаннями, що є теоретичною підвалиною дисциплін. При цьому враховувати закономірність взаємозв'язків i взаємозалежність у розвитку науки і практики, а також інтеграцію та диференціацію різноманітних галузей знання. Чим вищий рівень узагальнення знань, тим ширшою є сфера їх дії та, водночас, меншою кількість інформації, що необхідно засвоїти студентам. Головним об'єктом вивчення $€$ основні закономірності; усі факти потрібно розглядати насамперед як засіб розкриття сутності цих закономірностей. Крім цього, до змісту освіти треба вносити лише те нове, що вже пройшло наукову та практичну перевірку. Отже, зміст освіти, побудований на науковій основі відповідно до Нової української школи, зокрема діяльнісного та компетентнісного, має передбачати інтеграцію знань із дисциплін суміжних галузей для ефективного розв'язання вчителем у подальшому практичних завдань фізичного виховання.

У зв’язку з цим, «суть освіти полягає в тому, щоб дозволити студенту на будь-якому рівні стикатися 3 
важливими проблемами свого існування, щоб він усвідомлював проблеми і суперечливі питання, які він хотів би вирішити».

Запропонована точка зору прямо співвідноситься 3 ідеями про смисл, особистісну значимість змісту навчальної дисципліни і методів навчання. У зв'язку з цим відзначимо, що переживання сутності змісту навчальної дисципліни й освітнього процесу Нової української школи в цілому $є$ одним із найважливіших чинників, що забезпечують позитивну мотивацію, формування професійної спрямованості та ефективність навчання.

\section{Висновок}

У цілому, запропонований комплекс психологопедагогічних умов забезпечує досягнення мети і завдань професійної освіти, взаємозв' язок і оптимізацію навчальної, розвивальної та виховної функцій професійної підготовки вчителя; узгодженість і взаємодію змісту, форм, методів і технологій підготовки майбутніх учителів фізичного виховання; спрямування психолого-педагогічного компоненту професійної підготовки студентів на майбутню діяльність учителя фізичного виховання; сприяє створенню інноваційного освітнього середовища для формування комплексу компетентностей, необхідних учителям фізичного виховання, розвитку професійної спрямованості та на цій основі - педагогічної майстерності вчителя фізичного виховання.

\section{Література}

1. Ажиппо О.Ю. Підготовка майбутніх учителів фізичної культури до професійної діяльності в загальноосвітніх навчальних закладах (теоретичний i методичний аспекти). Харків: Цифрова друкарня № 1, 2012. 423 с.

2. Балахничева Г.В., Заремба Л. В., Цьось А. В.. Професійна майстерність учителя фізичного виховання. Луцьк: Східноєвроп. нац. ун-т ім. Лесі Українки, 2013. 64 с. 
3. Васянович Г.П. Педагог і його роль у навчальновиховному процесі. Офіцер України. 2013. № 8. С. 9-11.

4. Васянович Г.П. Педагогічна етика: навч.-метод. посібник. Львів: Норма, 2005. 344 с.

5. Гуревич Р.С., Кадемія М.Ю.. Інформаційнотелекомунікаційні технології в навчальному процесі та наукових дослідженнях: навч. посібник для студ. пед. ВНЗ і слухачів ін-тів післядипл. пед. Освіти. Вінниця: ООО «Планер», 2005. 366 с.

6. Гуревич Р.С. Теорія і практика навчання в професійнотехнічних закладах: монографія. Вінниця: ДОВ «Вінниця», 2008. 410 с.

7. Гуржій А.М., Гуревич Р.С., Коношевський Л.К. Формування професійної компетентності майбутніх учителів трудового навчання засобами інформаційнокомунікаційних технологій: монографія. Вінниця: ТОВ Фірма «Планер», 2015. 464 с.

8. Свтух М.Б. Педагогічна освіта // Енциклопедія освіти / В.Г. Кремень. Київ : Юрінком Інтер, 2008. С. 646.

9. Зязюн I.A. Інтелектуально-творчий розвиток особистості в умовах неперервної освіти. Неперервна професійна освіта: проблеми, пошуки, перспективи: монографія / за ред. І. А. Зязюна. Київ: Віпол, 2000. C. 11-57.

10. Зязюн I.А. Наука i мистецтво педагогічної дії. Професійна освіта: педагогіка і психологія. Польськоукраӥнський, украӥно-польський журнал / за ред. Т. Левовицького, І. Зязюна, І. Вільш, Н. Ничкало. Ченстохова; Київ, 2001. № 5. С. 357-380.

11. Зязюн I.А. Педагогічне наукове дослідження в контексті цілісного підходу. Порівняльна професійна педагогіка. 2011. Вип. 1. С. 19-30.

12. Ничкало Н.Г. Теоретичні засади становлення і розвитку субдисциплін у сучасній педагогіці. Eстетичне виховання дітей та молоді: теорія, практика, перспективи розвитку : збірник наукових пращьь / за ред. О. А. Дубасенюк, Н. Г. Сидорчук. Житомир : Вид-во ЖДУ ім. І. Франка, 2012. С. 23-33. 


\section{Фастовець I.A, Овчарова Н.А}

Психолого-педагогічні умови підготовки майбутніх учителів фізичного виховання Нової української школи

\section{Анотація}

У статті подано теоретичне обгрунтування реалізації педагогічних інновацій, спрямованих на підвищення ефективності Нової української школи, яка ставить завдання прискіпливого аналізу, усвідомлення й осмислення обставин, від яких залежать ефективність, успішність, якість освіти та визначення педагогічних умов, за яких їх упровадження $\epsilon$ можливим і доцільним у підготовці майбутніх учителів фізичної культури.Педагогічні умови та інші аспекти статті стосуються основних суб' єктів освіти, на поставлену мету і завдання, на підготовку майбутніх учителів фізичного виховання.

Ключові слова: позитивне ставлення, професійна компетентність,професійна мотивація,інновація, професійнопедагогічної підготовка студентів, фізичне виховання, здоров'язбереження, Нова українська школа.

\section{Фастовец И.А, Овчарова Н.А}

\section{Психолого-педагогические условия підготовки} будущих учителей физического воспитания Новой украинской школы

\section{Аннотация}

В статье представлено теоретическое обоснование реализации педагогических инноваций, направленных на повышение эффективности Новой украинской школы, задачу тщательного анализа, осмысления обстоятельств, от которых зависят эффективность, успешность, качество образования и определения педагогических условий, при которых их внедрение возможно и целесообразно в подготовке будущих учителей физической культуры. Педагогические условия и другие аспекты статьи касаются основных субъектов 
образования, поставленную цель и задачи, на подготовку будущих учителей физического воспитания.

\section{Ключевые слова: позитивное отношение,} профессиональная компетентность, профессиональная мотивация, инновация, профессионально-педагогической подготовки студентов, фискультурное воспитание, сохранение здоровья, Новаяукраинская школа. 